\title{
PERCEPTIONS OF THE DIMENSIONS OF WORK SUCCESS OF MANAGEMENT CONSULTANTS IN SOUTH AFRICA
}

\author{
M. ERASMUS \\ J. M. SCHEPERS
}

\author{
Department of Human Resource Management \\ Rand Afrikaans University
}

\begin{abstract}
OPSOMMING
Die hoofdoelstelling van die studie was om 'n meetinstrument te konstrueer waarmee die kritieke dimensies van die werk van bestuurskonsultante geïdentifiseer kan word. 'n Sekondêre doelstelling was om vas te stel of daar statisties beduidende verskille is tussen die persepsies van subgroepe van die steekproef. Die literatuur is deurskou en 53 bevoegdhede is gevind. Op grond van die bevoegdhede is die "Management Consulting Competency Questionnaire" (MCCQ) ontwikkel, bestaande uit twee stelle items. Die eerste stel het betrekking op die belangrikheid van verskeie bevoegdhede, en die tweede stel op die frekwensie waarmee daardie bevoegdhede gebruik word. Die items is deur 165 bestuurskonsultante beoordeel. Faktorontledings is uitgevoer en die resulterende faktore is verder aan ' $n$ interbatteryfaktorontleding onderwerp. Drie faktore is onttrek, naamlik konsultasievaardighede, konsultantpersoonlikheid en kliëntediensvaardighede. Die subgroepe is vergelyk deur Hotelling se $\mathrm{T}^{2}$ toets en MANOVA te gebruik. Statisties beduidende verskille is gevind in die persepsies van bestuurskonsultante ten opsigte van konsultantvlak en jare ervaring.
\end{abstract}

\begin{abstract}
The primary goal of this study was to contruct an instrument with which to identify the critical dimensions of the job of management consultants. A secondary goal was to determine whether there are any statistically significant differences in the perceptions of subgroups of the sample. The literature was studied and 53 competencies were found. Based on these competencies, the "Management Consulting Competency Questionnaire" (MCCQ) was developed, comprising two sets of items. The first set concerns the importance of various competencies, and the second set relates to the frequency with which the competencies are used. The items were judged by 165 management consultants. Factor analyses were carried out and the resulting factors were further subjected to an interbattery factor analysis. Three factors were identified, namely consulting skills, consultant personality and client service skills. The subgroups were compared using Hotelling's $\mathrm{T}^{2}$ test and MANOVA. Statistically significant differences were found in the perceptions of management consultants for consulting level and years experience.
\end{abstract}

World trends of globalisation and the information superhighway have catapulted South African organisations into a new era where business is fast and ever changing. The nature of business in this country, the sagging economy and the eminent privatisation of large state owned firms are factors creating discomfort in local management circles. Alnutt (1991) wrote that there is a shortage of the type of management skills needed to cope with these changes. This creates an increasing demand for management consulting services. Price (1991) supported this view by stating that South Africa needs strengthened, more widely available, more professionally equipped management consulting services, offered by consultants from a wider range of racial and cultural groups to raise the living standards for all South Africans through improved productivity. Management consultants must change the value system in the direction which they believe is most positive and constructive for the longer term future of the country and their businesses.

Following the trends and the general outcry for help, the number of management consulting firms and their approaches to client problems have increased significantly over the last few years. Some client firms are very happy with the outcome of their relationships with management consulting firms, whilst others are disappointed with the long timescales of projects, overspending and the little value added to the business. The "right" kind of help is thus still far short of the need.

In 1981 Block predicted that consultancies would be forced to become more specialised, clients would become much more demanding and that there will be an increasing split between resource and process consulting. A decade later Parsons (1993) remarked that new wave consulting bears a remarkable similarity to new wave managing. He suggested that management consulting will not work in the future until such time as everybody gets involved in improving whole systems. The role of consultants will therefore change from problem solving to the democratic design of whole systems. He described excellent consulting as building consensus and facilitating client learning. Good consulting merely comprises the providing of information, diagnosing of problems and the offering of recommendations. Parsons predicted that consultants will concentrate less on being right and making decisions and more on helping others learn, building support and mobilising energy.

Bader and Stich (1993) quoted examples in the European Community where clients are making half of the consulting firm's fee contingent on the successful completion of the project. Measures such as perceived impact, quality and customer service serve as criteria for the evaluation of projects. Consultants of the future will therefore be paid for performance. The question is one of what are the competencies of management consultants working for large management consulting firms in South Africa? For the sake of clarity, a large management consulting firm is defined as a consulting firm with more than 80 management consultants.

Consulting is described by Blake and Mouton (1987) as an intervention calculated to bring about change in a deliberate way. The consultant's function is to aid a person, a group, an organisation, or a larger social system by helping the client identify and break out of damaging cycles. Block (1981) provided an interesting perspective by describing a consultant as a person in a position where he has some influence over an individual, a group, or an organisation, but no direct power to make changes or implement programmes. A manager, on the other hand, is someone who has direct control over actions. The moment consultants take direct control, they are acting as managers.

Barcus and Wilkinson (1986) provided the most comprehensive definition of management consulting. They described it as an independent and objective advisory service provided by qualified individuals to clients, in order to help them identify and analyse management problems and opportunities. In essence, management consultants help to effect constructive changes in private or public sector organisations through the sound application of substantive and process skills. 
There is an ongoing debate surrounding the issue of whether management consulting has achieved professional status or not. In 1982 Greiner and Metzger still referred to management consulting as an adolescent venturing eagerly into the future. They maintained at the time that it had not achieved professional status independently from other professions from which consultants are drawn, for example organisation developers, engineers and accountants. Today, institutes such as the South African Institute of Chartered Accountants (SAICA) (1992) describe management consulting as a profession.

Due to the popularisation of the term, competencies also need to be defined in the context of this study. Buchanan and Boddy (1992) described a competency as an action, behaviour, or outcome which a person should be able to demonstrate. An element of competency might be described as the knowledge or understanding which is essential if performance is to be sustained, or extended to new situations within the occupation. Each element of competency has associated performance criteria which define the expected level of performance. Competencies can relate to any conceivable aspect of human behaviour at work - behaviours, actions, personality traits, understanding, skill, dealing with novelty, and the personal qualities brought to interpersonal relationships.

The service rendered by management consultants is complicated by its personalised nature (Kubr, 1988). The delivery of services occur in direct contact between the consulting firm and the client. The consultant does not operate from a power base, but as a specialist whose influence flows from competence, ideas and acceptance. There is also an emergence of a global standard in service delivery by management consultants. Many firms now follow a worldwide team approach which includes the use of consistent specialised methodologies for approaching complex tasks (Gallager, 1993).

Bader and Stich (1993) commented that projects vary in their scope and complexity and that the groundwork for all projects must therefore be laid very carefully. Projects can vary in terms of their political nature and in their product or process focus. The interrelationships between product, process and politics have to be managed carefully. Understanding these interrelationships can result in the design and construction of successful client-consultant relationships that meet clients' needs.

Lippit and Lippit (1986) described various consultant roles. They stated that consultant behaviour varies in its degree of directiveness. In the more directive role, the consultant assumes leadership and directs the activity. In the nondirective mode the consultant provides data, for the client to use or not, as a guide for self-initiated problem-solving. These roles are not mutually exclusive and may manifest at any time during the consulting project. They see the roles as spheres of competence rather than as a static continuum of isolated behaviours. The roles identified are expert, advocate, information specialist, trainer/educator, joint problem solver, identifier of alternatives and linker to resources, fact finder, process counsellor and objective observer.

In any consulting project an analytical approach and process is used by management consultants when consulting with clients. This involves the determination of client objectives, finding facts, defining opportunities and problems, evaluating alternatives, formulating proposed actions, communicating results, implementing results and conducting follow-ups (Barcus \& Wilkinson, 1986).

When consultants join a consulting firm, they get involved in various industries and work for clients ranging from privately owned business firms to governmental agencies and nonprofit organisations (Barcus \& Wilkinson, 1986). In order to deliver the types of services described, management consultants are managed fairly rigidly by their firms. This ensures the management of the quality and consistency of services to clients. It is expected of new consultants to master the essential consulting competencies before entering the operating consultant level. Galagan (1993) wrote that Andersen Consulting gives most of its training at the start of their consultants' career ladder. Supervisory consultants provide team leadership and experience on assignments, while principal consultants carry out a great number of marketing and middle-management functions. Senior and top management responsibilities are carried out at partner or director level (Kubr, 1988).

A problem that arises, is that many management consultants are neither comfortable with the wide variety of industries and services they are involved in, nor with the level of responsibilities they have to carry. This leads to a high turnover in the management consulting industry. Clients, on the other hand, feel that management consultants are trying to take over managers' roles.

There has to date been very little achieved in elucidating or identifying the competencies that form the dimensions of management consulting success. The complexity pertaining to the assessment of management consulting competence can be described by recognising that the mere learning of intervention techniques and procedural ways to be more effective, are insufficient (Block, 1981). It is therefore of critical importance to determine, as a first step, the perceptions of management consultants of the dimensions of work success in their daily activities.

Previous research can be divided into two distinct areas. In the first place it includes authors who provide lists of competencies and in the second place authors who attempt to provide groupings of competencies or dimensions related to management consulting success. For both areas, the results are varied. The numbers of competencies included in lists provided by authors, vary between six and 13. Of the authors and bodies that present their results in this manner, the SAICA offers the most comprehensive list.

Interestingly, Bell and Nadler (1979) and Buchanan and Boddy (1992) placed strong emphasis on problem solving and analytical abilities in their lists; largely ignoring the abilities of management consultants needed for interaction with clients. This negates the personalised nature of the service rendered. Kubr (1988), Bader and Stich (1993) and the SAICA (1992) on the other hand, emphasised the interpersonal and personality characteristics of management consultants. They included competencies such as maturity, the ability to persuade and motivate, ambition and physical and mental health in their lists. None of the findings reported, however, offer any substantiating empirical evidence.

Greiner and Metzger (1983) provided a list of seven competencies that include a balance of technical competence and personality factors. They described consulting as activities which centre in the quality of the interaction of consultants with clients. They maintained that success or failure of the consulting project depends on the multifaceted skills that consultants bring to the client's situation. In their study, numerous interviews were conducted with consultants. Seven competencies were described based on observation and experience. The authors offer no further substantiating data.

Block (1981) identified consulting skills, personal attributes and techniqal qualities. He classified consulting skills according to the phases of a consulting project. He relied solely on experience in deriving these factors and although this is often the best tool for hypothesis generation, his explanation warrants empirical testing.

Lippit and Lippit (1986) used a questionnaire to obtain data from 32 consultants. The results obtained were varied, but certain trends came to the fore: the competencies seemed to cluster in the categories of knowledge, skills and attitudes, based on their own identification of key areas of expertise. The 
results can, however, not be viewed as well founded, because of the small sample used and the subjective identification of the factors.

Moline (1990) focused on the training needs of management consultants and based his findings on his own experience gained in the management consulting field. He wrote that new consultants need intensive preparation, because of the complex world they enter and should then follow a specific curriculum path of management consultants, starting with the learning of the necessary consulting skills, followed by project management skills, practice management skills, functional skills and industry and market skills. He is the only author that has identified practice management skills - those skills related to the internal management of the firm.

An interesting research study was carried out by Kable (1991) who measured the preferences of successful consultants and the link between their preferences and skills when working with clients. The research was carried out involving 317 consultants in a major international consultancy organisation over a period of nine months as part of the development of the technique known as Decision Preference Analysis (DPA). The research clearly showed that successful consultants have a particular preference profile. This profile includes social, selling, creative, outdoor, practical, mathematics, scientific and clerical preferences. Kable concluded that consultancy is predominantly a qualitative profession and suggested that training should focus on selling, communication, group decision making and negotiation skills.

From the review of the available literature, it is clear that whilst there is no absence of studies in this field, few authors provide substantiating empirical evidence to support their findings. There is no clear pattern found for either the lists of competencies provided or the dimensions identified. The current research therefore has two objectives. The primary objective of this study is to develop an instrument with which to identify those competencies perceived to distinguish competent from incompetent consultants. Secondly, to determine whether the perceptions of subgroups of management consultants, formed on the basis of varying job levels, academic qualifications and years of experience, are similar or not.

The principal objective of the present study thus concerns the identification of the critical dimensions perceived to determine the work success of management consultants. It is not intended to measure the actual competencies of these consultants. The following hypotheses concern the secondary objective of the study:

$\mathrm{H}_{1}$ : The overall hypothesis is that there is a statistically significant difference in the vectors of means of the perceptions of graduates and post-graduates in respect of the various scales of the MCCQ.

Furthermore, it is postulated that the mean scores of the perceptions of graduates and postgraduates will differ statiscally significantly in respect of each of the various scales of the MCCQ.

$\mathrm{H}_{2}$ : The overall hypothesis is that there is a statistically significant difference in the vectors of means of the perceptions of consultants, senior consultants, principal consultants and partners in respect of the various scales of the MCCQ.

Furthermore, it is postulated that the mean scores of the perceptions of the four groups of respondents belonging to the various consulting job levels, will differ statistically significantly in respect of the various scales of the MCCQ.

$\mathrm{H}_{3}$ : The overall hypothesis is that there is a statistically significant difference in the vectors of means of the perceptions of the three groups of consultants with varying years of experience $\left(0-3\right.$ years, $4-7$ years and $7^{+}$years) in respect of the various scales of the MCCQ.
Furthermore, it is postulated that the mean scores of the perceptions of the three groups of consultants with varying years of experience will differ statistically significantly in respect of the various scales of the MCCQ.

\section{METHOD}

\section{Sample}

The sample was drawn from eight large management consulting firms in South Africa. This excludes independent consultants, small consulting firms and internal consultants. The larger firms typically handle longer term projects involving larger teams than the small consultancies. Respondents were included according to their availability. Men and women were included from various consulting levels with different levels of qualifications and varying years of experience in the management consulting field.

The large percentage of male respondents is representative of the predominantly male management consulting population of South Africa. The skewness of the sample towards higher levels of academic qualification are the same across all eight firms and results mainly from the strong competition between them for the best talent. The high percentage of consultants with 0-3 years working experience (56\%), reflects the growth of the industry in recent years and the eagerness of young graduates to work in this field. The distribution of participants regarding these variables is represented in Table 1 .

\section{TABLE 1 \\ DISTRIBUTION OF PARTICIPANTS ACCORDING TO BIOGRAPHICAL/DEMOGRAPHICAL VARIABLES}

\begin{tabular}{ll}
\hline DEMOGRAPHIC VARIABLES & $\underline{\mathbf{n}}$ \\
\hline CONSULTING LEVEL & \\
Graduate consultant/Consultant & $56(34 \%)$ \\
Senior consultant & $59(36 \%)$ \\
Principal consultant & $31(19 \%)$ \\
Director/Partner & $19(11 \%)$ \\
\hline GENDER & \\
Male & $119(72 \%)$ \\
Female & $46(28 \%)$ \\
\hline ACADEMIC QUALIFICATIONS & $3(2 \%)$ \\
Matric & $16(9 \%)$ \\
Diploma & $62(38 \%)$ \\
Degree & $84(51 \%)$ \\
Post-graduate qualification & \\
\hline YEARS OF EXPERIENCE & $93(56 \%)$ \\
$0-3$ years & $47(29 \%)$ \\
$4-7$ years & $25(15 \%)$ \\
$7+$ years &
\end{tabular}

Note: $\mathrm{n}=$ Number of participants

Percentages are given in parentheses

\section{Measuring Instrument}

To establish what constitutes competent job performance by management consultants, it was necessary to ascertain which constructs authors used when describing the performance of management consultants. A preliminary list of competencies was compiled based on previous research (cf. Bell \& Nadler, 1979; Block, 1981; Buchanan \& Boddy, 1992; Greiner \& Metzger, 1983; Kable, 1991; Kubr, 1988; Lippit \& Lippit, 1986; Miller, 1992; SAICA, 1992). To evaluate and refine the list, a pilot study was done at one of the firms. This firm was chosen because of the access the author had to the consultants. The ten experienced consultants and partners provided the final list of 53 competencies as they are provided in Table 2. From an inspection of this table, it becomes clear that the competencies can be loosely grouped into expert knowledge and skills, analytical and problem solving abilities, personality traits and clients service skills.

Based on the final list, a questionnaire was compiled. The questionnaire was named the Management Consulting 
TABLE 2

DIMENSIONS OF MANAGERIAL CONSULTING SUCCESS (Compiled from Bell \& Nadler, 1979; Block, 1981; Buchanan \& Boddy, 1992; Greiner \& Metzger, 1983; Kable, 1991; Kubr, 1988; Lippit \& Lippit, 1986; Miller, 1992; SAICA, 1992).

\section{COMPETENCIES}

1. Insight in problems leading to successful solutions

2. Analytical skills - the ability to integrate facts

3. Understanding group dynamics

4. Understanding business

5. The ability to withstand time pressures and work long hours

6. The ability to cope with irregular living conditions and extensive travelling

7. Expert industry knowledge

8. Expert technical or functional knowledge

9. Empathy - the awareness of others' feelings

10. Marketing skills - image building of the firm

11. The ability to establish human contacts easily

12. The ability to envision future developments and build scenarios and future strategies for clients

13. The ability to gain confidence and respect

14. Integrity in accepting only work within own skills and capabilities

15. The ability to speak or learn languages

16. The ability to delegate tasks and responsibilities to others

17. The ability to maintain confidentiality

18. Courage to experiment with different solutions

19. The ability to assess alternatives in terms of advantages and disadvantages (Cost-Benefit Analysis)

20. The ability to work with advanced technology

21. The ability to take risks when faced with uncertainty

22. The ability to control budgets, resources and time of projects

23. The ability to remain objective

24. The ability to organise activities for projects

25. The need for recognition/ambition

26. Solution development skills

27. Behavioural intervention skills

28. Group intervention skills

29. Fact-finding skills

30. The ability to separate symptoms and causes of problems

31. Questioning and interviewing skills

32. Project planning skills

33. The ability to make sound judgements when only confusing and meagre facts are available

34. The ability to transfer knowledge and skills to clients

35. The ability to determine power and politics in organisations

36. The ability to secure "win-win" agreements

37. Empathic listening skills

38. Written communication skills

39. The ability to handle conflict

40. The ability to be proactive

41. Oral and presentation skills

42. The ability to respect direct and indirect authority

43. Political skills - the ability to form alliances

44. The ability to network and build contacts

45. Poise and control

46. Self-knowledge and evaluation

47. Independence of viewpoints

48. Leadership ability - the ability to create a common goal amongst people

49. The ability to design creative solutions

50. Flexibility - the ability to adapt to changing environments

51. Diplomacy and a professional attitude

52. Self-confidence - the ability to make an immediate impact

53. Curiosity - staying abreast with the latest trends through reading, research and discussion

Competency Questionnaire (MCCQ). In a second pilot study, the MCCQ was evaluated by 20 management consultants belonging to varying consulting levels from the same consulting firm to determine the relevance and clarity of each question. Changes were made to the MCCQ as a result of this study. The final version of the MCCQ, resulting from the process described above, comprised 104 questions regarding managerial consulting success. The items were divided into two sets, namely 56 items relating to importance and 48 items to frequency of use. Each of the items of the MCCQ were rated on a seven-point scale by the participants.

\section{Procedure}

The questionnaires were distributed via co-ordinators (partners and personnel practitioners) at eight large management consulting firms in South Africa. Informed consent was given by partners of the firms and it was decided that neither the identities of the firms nor the names of consultants would be disclosed. This ensured the confidentiality of the data. A total number of 210 questionnaires were distributed and 165 (79\%) were returned over a period of three months. Some questionnaires were not returned because the consultants had unexpected assignments elsewhere at the time of the study. A long lapse of time was allowed to ensure that at least some of the consultants assigned on "out-of-town" assignments could be included in the sample.

\section{Statistical Analyses}

Based on the fact that there were a large number of items, namely 104 , and a relatively small sample, namely 165 , it was decided to divide the MCCQ into two sets of items, viz. 56 items of importance and 48 items of frequency. The two sets of 
items were then to be analysed separately in order to determine the basic constructs underlying each of the sets of items. Finally, the dimensions common to the two sets of items were to be established by means of an interbattery factor analysis.

The interbattery factor analysis procedure was developed by Tucker (1958) and adapted by Browne (1979). As this procedure has already been described in detail in a previous journal article by Swanefelder and Schepers (1992), it will not be described in great detail here. Suffice it to say that Browne developed a maximum-likelihood solution for Tucker's model. He found that the estimates of the interbattery factor loadings could be obtained by scaling the correlations of the original variables with the canonical variates (Browne, 1979). The programme used in the study by Swanefelder and Schepers was the INT-BAT programme of the HSRC that is based on Browne's solution. For the present study the MBFACT (Multiple Battery Factor Analysis) programme, which is a revision of the INT-BAT programme, will be used. The INTBAT programme was revised in 1986 and 1991, however, the basic procedure remained the same - only small refinements were made to the programme.

To start off with the dimensionality of the two sets of items will be determined by means of principal factor analysis, followed by a second-order factor analysis of the simplified factor scores underlying the first order factors. This procedure will be followed to get rid of artefactors generated by differentially skew items (cf. Schepers, 1992).

Once the true factors underlying the two sets of items have been identified, scores will be computed for each person in respect of each of these factors. These scores will be used as input to the interbattery factor analysis.
Once the common factors underlying the two sets of items have been identified, the items having high loadings on each of the factors will be grouped to form separate scales. Each of these scales will then be subjected to item analysis using the NP50 programme of the NIPR, and the reliabilities of the scales will be estimated according to Cronbach's coefficient alpha.

For the second objective of the study, namely to test whether there are statistically significant differences between perceptions of subgroups of the sample, Hotelling's T ${ }^{2}$ will be used in the case of two groups, and MANOVA and ANOVA for three or more groups.

\section{RESULTS}

The 165 completed quesionnaires were analysed statistically. The 56 items of importance were intercorrelated and subjected to a first-order factor analysis yielding 18 factors which were rotated to simple structure by means of the varimax rotation. Simplified factor scores for each of the 18 factors were computed and these subscores were intercorrelated and subjected to a second-order factor analysis. The factor matrix was obliquely rotated to simple structure using the Direct Oblimin procedure. Six second-order factors were extracted by this process. The same procedure was followed for the 48 items of frequency. The first-order factor analysis yielded 16 factors and the second-order factor analysis yielded five factors. Because of the size of the tables for this part of the study, they will not be reproduced here, but are available on request.

Scores were next computed for each person in respect of the six scores of importance and five scores of frequency. These scores were intercorrelated yielding an 11 by 11 intercorrelation matrix. This matrix was used as input to the interbattery factor analysis and is given in Table 3 .

TABLE 3

INTERCORRELATION MATRIX (11 x 11)

\begin{tabular}{|c|c|c|c|c|c|c|c|c|c|c|c|c|}
\hline & & \multicolumn{6}{|c|}{ IMPORTANCE } & \multicolumn{5}{|c|}{ FREQUENCY } \\
\hline & & SFS1 & SFS2 & SFS3 & SFS4 & SFS5 & SFS6 & SFS7 & SFS8 & SFS9 & SFS10 & SFS11 \\
\hline \multirow{6}{*}{ 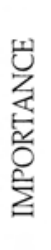 } & SFS1 & 1,000 & & & & & & & & & & \\
\hline & SFS2 & 0,481 & 1,000 & & & & & & & & & \\
\hline & SFS3 & 0,433 & 0,204 & 1,000 & & & & & & & & \\
\hline & SFS4 & 0,486 & 0,278 & 0,357 & 1,000 & & & & & & & \\
\hline & SFS5 & 0,281 & 0,136 & 0,223 & 0,142 & 1,000 & & & & & & \\
\hline & SFS6 & 0,175 & 0,144 & 0,281 & 0,156 & 0,171 & 1,000 & & & & & \\
\hline \multirow{5}{*}{ 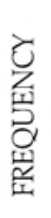 } & SFS7 & 0,472 & 0,757 & 0,270 & 0,340 & 0,130 & 0,369 & 1,000 & & & & \\
\hline & SFS8 & 0,371 & 0,235 & 0,189 & 0,259 & 0,364 & 0,352 & 0,436 & 1,000 & & & \\
\hline & SFS9 & 0,535 & 0,316 & 0,513 & 0,377 & 0,354 & 0,338 & 0,468 & 0,456 & 1,000 & & \\
\hline & SFS10 & 0,219 & $-0,008$ & 0,142 & 0,093 & 0,057 & 0,240 & 0,064 & 0,217 & 0,214 & 1,000 & \\
\hline & SFS11 & 0,200 & 0,085 & 0,188 & 0,335 & 0,015 & 0,144 & 0,167 & 0,245 & 0,197 & 0,086 & 1,000 \\
\hline
\end{tabular}

The Multiple Battery Factor Analysis starts by extracting one factor only and then determines the goodness of fit of the model to the data. In the present study, it turned out that more than one factor was indicated. Two, three and four factors were extracted accordingly. In this particular case not more than five factors could be extracted, because the smallest battery comprised five scales only. A summary of the goodness of fit statistics appears in Table 4 . From an inspection of Table 4 it can be seen that the test statistic $(-2 / n \lambda)$ declines in value as more factors are extracted. The upper tail probability of this statistic is 0,025 for four factors, and the average absolute offdiagonal residual is 0,0373 , indicating a good fit of the model to the data. The test statistic actually gives an indication of the lack of fit of the model to the data. The smaller the upper tail probability, the poorer the fit. The Tucker-Lewis reliability coefficient increases as more factors are extracted reaching a value of 0,980 for four factors. According to Tucker (1973, p. 5) this coefficient "may be interpreted as indicating how well a factor model with $m$ common factors represents the covariances among the attributes for a population of objects. Lack of fit would indicate that the relations among the attributes are more complex than can be represented by $m$ common factors."

After studying the four factor solution it appeared that the fourth factor is in fact a fragment of the third factor - a factor fission had taken place, because too many factors were extracted. Accordingly, three factors were used.

The resulting factor matrix was rotated to simple structure using the Direct Quartimin procedure. The final rotated solution is given in Table $5 \mathrm{a}$ and the matrix of intercorrelations of the three factors is given in Table $5 \mathrm{~b}$. It appears that the three factors are moderately correlated with one another. 
TABLE 4

GOODNESS OF FIT AS A FUNCTION OF NUMBER OF FACTORS

\begin{tabular}{lrrrr}
\hline & \multicolumn{3}{c}{ NUMBER OF FACTORS EXTRACTED } \\
& \multicolumn{1}{c}{1} & \multicolumn{1}{c}{2} & 3 & 4 \\
\hline TEST STATISTIC $(-2 \ln \lambda)$ & 110,746 & 37,140 & 18,450 & 7,847 \\
DEGREES OF FREEDOM & 20,000 & 12,000 & 6,000 & 2,000 \\
UPPER TAIL PROBABILITY & 0,000 & 0,000 & 0,005 & 0,025 \\
TUCKER-LEWIS RELIABILITY COEFFICIENT & 0,616 & 0,875 & 0,942 & 0,980 \\
AVERAGE ABSOLUTE OFF-DIAGONAL RESIDUAL & 0,1097 & 0,0489 & 0,0441 & 0,0373 \\
LARGEST COMMUNALITY & 0,7873 & 0,8055 & 0,8078 & 0,8078 \\
\hline
\end{tabular}

TABLE $5 a$

ROTATED FACTOR MATRIX (DIRECT QUARTIMIN ROTATION)

\begin{tabular}{|c|c|c|c|c|}
\hline & VARIABLES & FACTOR I & FACTOR II & FACTOR III \\
\hline \multirow{6}{*}{ 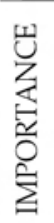 } & SFS1 & 0,246 & 0,303 & 0,355 \\
\hline & SFS2 & 0,869 & $-0,073$ & 0,012 \\
\hline & SFS3 & $-0,021$ & 0,079 & 0,627 \\
\hline & SFS4 & 0,139 & 0,028 & 0,482 \\
\hline & SFS5 & $-0,077$ & 0,609 & $-0,040$ \\
\hline & SFS6 & 0,244 & 0,372 & 0,059 \\
\hline \multirow{5}{*}{ 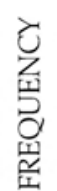 } & SFS7 & 0,848 & 0,059 & 0,072 \\
\hline & SFS8 & 0,163 & 0,640 & $-0,068$ \\
\hline & SFS9 & 0,081 & 0,377 & 0,505 \\
\hline & SFS10 & 0,070 & 0,272 & 0,135 \\
\hline & SFS11 & $-0,010$ & $-0,079$ & 0,447 \\
\hline
\end{tabular}

TABLE $5 b$

MATRIX OF INTERCORRELATIONS OF FACTORS

\begin{tabular}{lccc}
\hline & FACTOR I & FACTOR II & FACTOR III \\
\hline FACTOR I & 1,000 & & \\
FACTOR II & 0,303 & 1,000 & \\
FACTOR III & 0,379 & 0,447 & 1,000 \\
\hline
\end{tabular}

The items loading on each of the factors were next identified. Using the NP50 programme, an item analysis was performed in respect of Scale I (Consulting Skills) with 25 items (Table 6), Scale II (Consulting Personality) with 28 items (Table 7) and Scale III (Client Service Skills) with 51 items (Table 8). The reliabilities of Scales I, II and III according to Cronbach's coefficient alpha are 0,873,0,776 and 0,896, respectively.

An ancillary objective of this study was to determine whether there are any statistically significant differences in the perceptions of the subgroups of the sample. From Table 9 it is apparent that there is no statistically significant difference in the vectors of means of graduates and postgraduates. Hotelling's $\mathrm{T}^{2}=2,292$, with an associated F $(3,142)=0,96$, $p=0,4137$. Accordingly, there is no support for Hypothesis 1 .

The results of the MANOVA for the four groups belonging to different consulting levels, are shown in Table 10. From an inspection of the table, it appears that Wilks' coefficient lambda is equal to 0,70 , with an associated $F(3,159)=6,73$, $p=0,00001$. The overall null-hypothesis is therefore rejected. From the ANOVA, it is apparent that there is a statistically significant difference in the group means in respect of Scale I (Consulting Skills). F $(3,161)=15,89, \mathrm{p}<0,00001$. Accordingly, Scheffé's post-hoc multiple comparisons technique was used to determine which groups differed from one another. From the results, it is clear that the perceptions of consultants and

TABLE 6

ITEM STATISTICS IN RESPECT OF SCALE I OF THE MCCQ

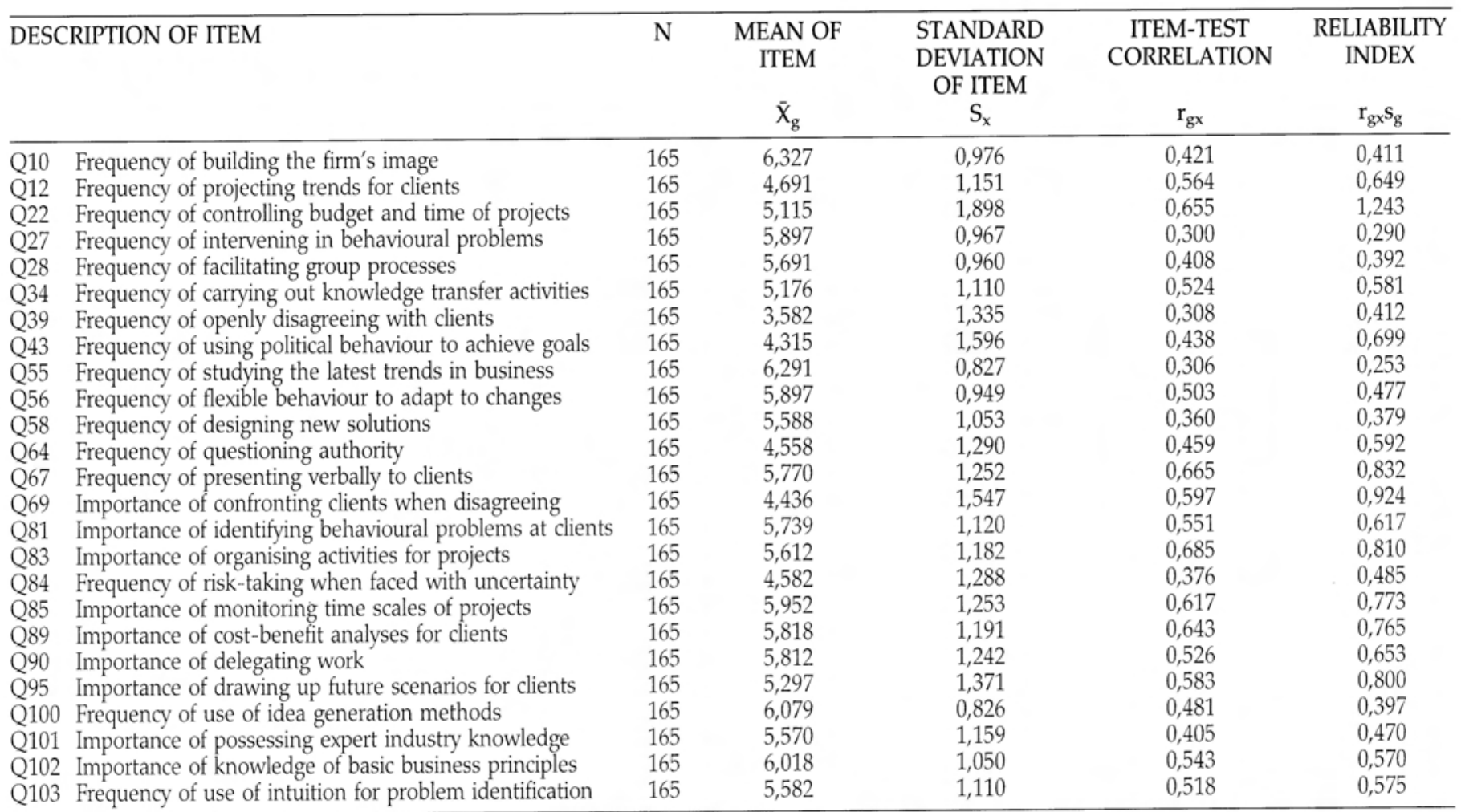

Cronbach coefficient Alpha $=0,873 \quad$ Number of items $=25$ 
TABLE 7

ITEM STATISTICS IN RESPECT OF SCALE II OF THE MCCQ

\begin{tabular}{|c|c|c|c|c|c|}
\hline DESCRIPTION OF ITEM & $\mathrm{N}$ & $\begin{array}{c}\text { MEAN OF } \\
\text { ITEM } \\
\overline{\mathrm{X}}_{\mathrm{g}}\end{array}$ & $\begin{array}{c}\text { STANDARD } \\
\text { DEVIATION } \\
\text { OF ITEM } \\
S_{x} \\
\end{array}$ & $\begin{array}{c}\text { ITEM-TEST } \\
\text { CORRELATION }\end{array}$ & $\begin{array}{l}\text { RELIABILITY } \\
\text { INDEX }\end{array}$ \\
\hline Q14 Importance of declining projects not skilled for & 165 & 5,509 & 1,447 & 0,323 & 0,468 \\
\hline Q15 Frequency of using the ability to speak more than one language & 165 & 3,261 & 1,663 & 0,279 & 0,463 \\
\hline Q16 Frequency of solving problems alone to control the outcome & 165 & 4,848 & 1,223 & 0,431 & 0,527 \\
\hline Q20 Frequency of working with advanced technology & 165 & 5,394 & 1,141 & 0,342 & 0,390 \\
\hline Q21 Importance of risk-taking when faced with uncertainty & 165 & 4,915 & 1,246 & 0,358 & 0,447 \\
\hline Q23 Importance of relying on feelings rather than facts & 165 & 3,036 & 1,383 & 0,269 & 0,373 \\
\hline Q33 Importance of postponing solution decisions when facts are meager & 165 & 5,776 & 1,196 & 0,244 & 0,291 \\
\hline Q38 Importance of written communication skills & 165 & 6,115 & 1,171 & 0,286 & 0,335 \\
\hline Q40 Frequency of creating proactive solutions for future problems & 165 & 4,103 & 1,314 & 0,376 & 0,495 \\
\hline Q44 Frequency of networking activities carried out to build contacts & 165 & 5,527 & 0,947 & 0,313 & 0,297 \\
\hline Q47 Importance of supporting the client even when facts show otherwise & 165 & 2,964 & 1,379 & 0,453 & 0,625 \\
\hline Q48 Frequency of persuasion to move people to obtain certain goals & 165 & 5,055 & 1,002 & 0,434 & 0,435 \\
\hline Q49 Importance of only using tested methodologies & 165 & 3,806 & 1,546 & 0,399 & 0,617 \\
\hline Q51 Frequency of the need to display diplomatic behaviour & 165 & 5,248 & 1,285 & 0,394 & 0,507 \\
\hline Q52 Frequency of situations where consultants have to defend abilities & 165 & 4,158 & 1,490 & 0,282 & 0,420 \\
\hline Q60 Importance of supporting the client in all situations & 165 & 3,570 & 1,635 & 0,431 & 0,705 \\
\hline Q65 Importance of forming political alliances & 165 & 4,291 & 1,469 & 0,309 & 0,455 \\
\hline Q68 Frequency of the preparation of written communication for clients & 165 & 4,539 & 1,212 & 0,321 & 0,389 \\
\hline Q71 Importance of negotiating "win-win" solutions & 165 & 5,339 & 1,295 & 0,425 & 0,550 \\
\hline Q72 Frequency of data analyses & 165 & 4,788 & 1,224 & 0,373 & 0,457 \\
\hline Q73 Importance of the ability to transfer knowledge to clients & 165 & 5,788 & 1,130 & 0,311 & 0,352 \\
\hline Q75 Importance of the ability to generate several alternatives & 165 & 4,727 & 1,398 & 0,570 & 0,797 \\
\hline Q80 Frequency of recognition rewards consultants should get & 165 & 5,497 & 1,203 & 0,238 & 0,286 \\
\hline Q82 Frequency of being objective when advising clients & 165 & 4,812 & 1,272 & 0,447 & 0,569 \\
\hline Q87 Frequency of experimentation with different solutions & 165 & 4,321 & 1,538 & 0,554 & 0,852 \\
\hline Q88 Frequency of opposing clients when their agreement is broken & 165 & 3,800 & 1,380 & 0,475 & 0,656 \\
\hline Q91 Frequency of refusing projects on the base of lack of skills & 165 & 3,612 & 1,625 & 0,445 & 0,723 \\
\hline Q98 Importance of expert technical or functional knowledge & 165 & 5,485 & 1,281 & 0,477 & 0,612 \\
\hline
\end{tabular}

Cronbach Coefficient Alpha $=0,776 \quad$ Number of items $=28$

senior consultants differed statistically significantly, as well as the perceptions of seniors and principals. The perceptions of principal consultants and partners did not differ statistically significantly. There were no statistically significant differences in respect of Scales II and III. Hypothesis 2 is therefore only partially supported. These results are given in Table 11.

The results of the MANOVA for the three groups of differing years of experience, are given in Table 12. From an inspection of the table, it appears that Wilks' coefficient lambda is equal to 0,87 , with an associated $\mathrm{F}(6,320)=3,98, p=0,0007$. The overall null-hypothesis is therefore rejected. From the ANOVA, it is apparent that there is a statistically significant difference in the group means in respect of Scale I (Consulting Skills). F $(2,162)=9,37, p=0,0001$. Accordingly, Scheffé's post-hoc multiple comparisons technique was used to determine which group perceptions differ from one another. From the results, it is clear that the perceptions of the group with $0-3$ years of experience differed statistically significantly from both the groups of 4-7 years and 7+ years experience. The perceptions of the groups with 4-7 years and 7+ years did not, however, differ statistically significantly. Hypothesis 3 is therefore partially supported. These results are given in Table 13.

\section{CONCLUSION}

The findings of this exploratory study can be seen as the first step in defining a competency model for management consultants working for large management consulting firms in South Africa. Three scales were identified that are perceived to underlie the success of management consultants, namely Consulting Skills, Consultant Personality and Client Service Skills. Thus the findings of the present study agree fairly closely with the findings of Block (1981) who identified technical skills, personal attributes and consulting skills. Block categorised consulting skills according to the phases of the consulting project, which agrees closely with Scale III of the present study, namely Client Service Skills.

In respect of Consulting Skills (Scale I), there were statistically significant differences found in the perceptions of groups of consultants belonging to various consulting levels. There is a perception that the acquisition of consulting skills are augmented as a consultant moves through the various levels of consulting. This is supported by the statistically significant differences between consultants and senior consultants, and senior consultants and principal consultants. No statistically significant difference was, however, found between principal consultants and partners. This can be attributed to the fact that partners are not perceived to be as involved in day-to-day consulting, but rather focus on marketing and managing activities.

A similar result was found in respect of the perceptions of groups with varying years of experience, with 0-3 years differing statistically significantly from $4-7$ years and $7+$ years in respect of Consulting Skills (Scale I). There is therefore a perception that there is no significant increase in the skills of successful management consultants after four years in the industry.

In respect of Consulting Personality (Scale II), there were no statistically significant differences in the perceptions of subgroups of the sample. This implies that there is consensus concerning a specific personality profile for all successful management consultants irrespective of consulting level, academic qualification or years of experience of the respondents.

In respect of Client Service Skills (Scale III), no statistically significant differences were found in the perceptions of subgroups of the sample, irrespective of consulting level, 
TABLE 8

ITEM STATISTICS IN RESPECT OF SCALE III OF THE MCCQ

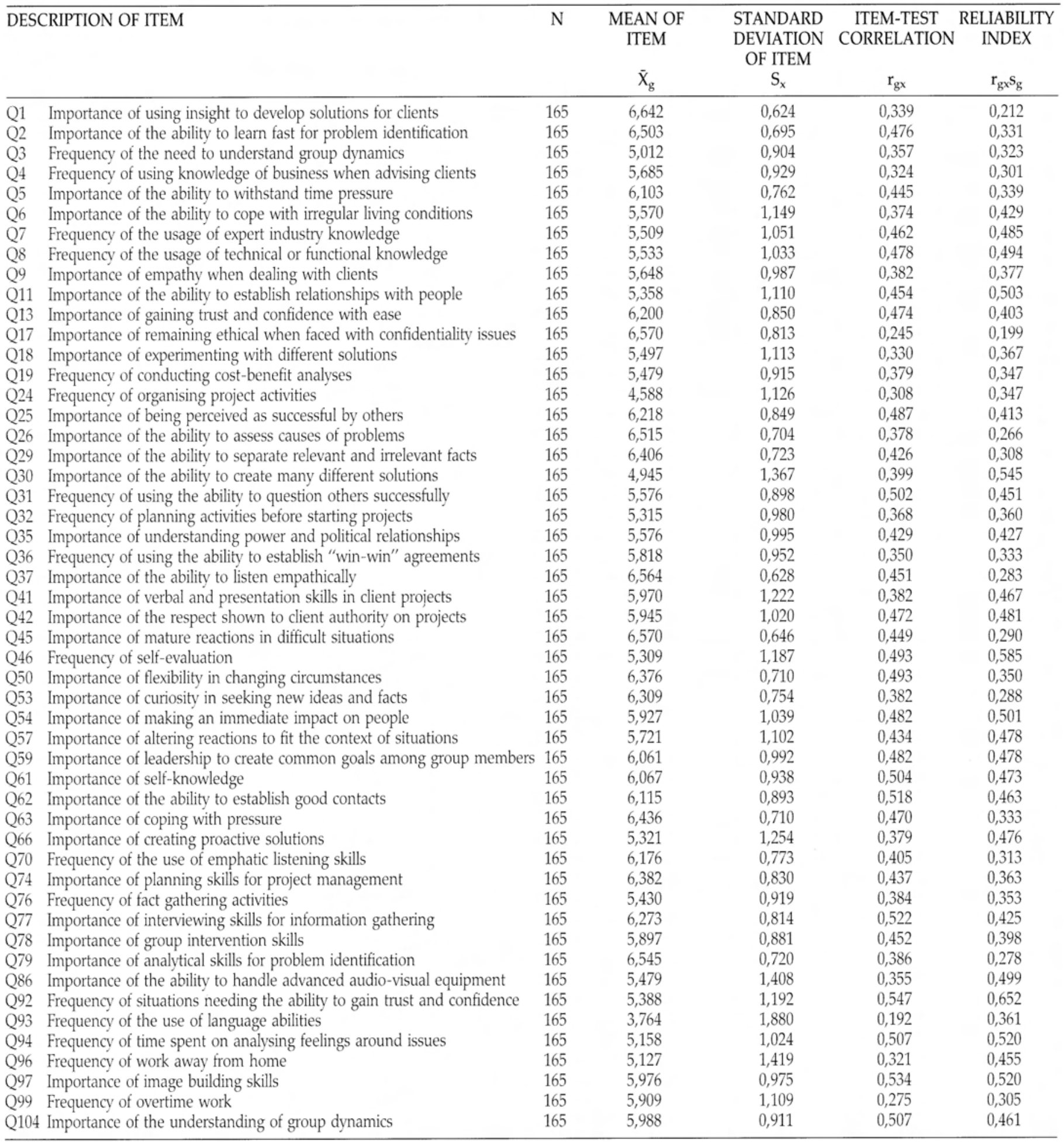

Cronbach Coefficient Alpha $=0,896$ Number of items $=51$

TABLE 9

SIGNIFICANCE OF DIFFERENCES OF MEANS BETWEEN GRADUATES AND POST-GRADUATES IN RESPECT OF THE THREE SCALES OF THE MCCQ: HOTELLING'S T ${ }^{2}$ FOR INDEPENDENT SAMPLES

\begin{tabular}{|c|c|c|c|c|c|c|c|c|c|c|c|c|}
\hline \multicolumn{4}{|c|}{ GRADUATES } & \multicolumn{3}{|c|}{ POST-GRADUATES } & \multirow[b]{2}{*}{ Levene F } & \multirow[b]{2}{*}{ df } & \multirow[b]{2}{*}{$\mathrm{p}(\mathrm{F})$} & \multirow[b]{2}{*}{ t-value } & \multirow[b]{2}{*}{ df } & \multirow[b]{2}{*}{$\mathrm{p}(\mathrm{t})$} \\
\hline Variable & $\bar{X}_{1}$ & $\mathrm{~S}_{1}$ & $\mathrm{~N}_{1}$ & $\bar{X}_{2}$ & $\mathrm{~S}_{2}$ & $\mathrm{~N}_{2}$ & & & & & & \\
\hline$X_{1}$ & 132,7079 & 15,7869 & 62 & 136,0714 & 14,6787 & 84 & 0,13 & $1 \& 144$ & 0,7170 & $-1,32$ & 144 & 0,1874 \\
\hline$X 2$ & 130,2419 & 14,0417 & 62 & 129,0714 & 13,3937 & 84 & 0,02 & $1 \& 144$ & 0,8801 & 0,51 & 144 & 0,6099 \\
\hline X3 & 294,0484 & 22,5501 & 62 & 295,8571 & 18,5441 & 84 & 2,08 & $1 \& 144$ & 0,1513 & $-0,53$ & 144 & 0,5961 \\
\hline
\end{tabular}

Hotelling $\mathrm{T}^{2}=2,9196 \quad \mathrm{df}=3$ and 142

F-value $=0,9597 \quad \mathrm{p}=0,4137$ (Not significant) 
TABLE 10

MANOVA AND ASSOCIATED ANOVA' OF JOB LEVELS IN RESPECT OF THE THREE SCALES OF THE MCCQ

\begin{tabular}{cccc}
\hline Wilks' Coefficient Lambda & $\mathrm{F}$ & $\mathrm{df}$ & $\mathrm{p}$ \\
0,701909 & 6,73 & $3 \& 159$ & $<0,00001^{*}$ \\
& & & \\
X1 & 15,89 & $3 \& 161$ & $<0,00001^{*}$ \\
X2 & 0,31 & $3 \& 161$ & 0,8191 \\
X3 & 0,32 & $3 \& 161$ & 0,8121 \\
\hline
\end{tabular}

* Statistically significant

academic qualification or years of experience of the respondents. Interestingly, Scale III contains items that relate to both consulting skills and consulting personality, as applied in client service.

The basic findings of the study are depicted in the model below.

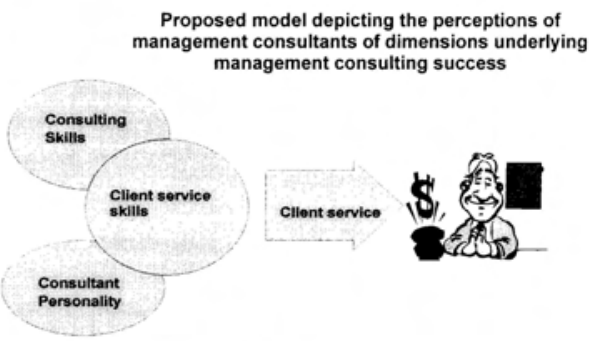

The knowledge gained in this study of the perceptions of management consultants of the dimensions underlying their work success, is the first step toward improving the management of performance of management consultants in management consulting firms in South Africa. A follow-up study is suggested to test the dimensions identified and the manifestation of the competencies in the actual behaviour of successful management consultants. From the findings of such a study, it would then be possible to develop accurate competency assessment techniques for the management consulting industry.

TABLE 11

SCHEFFE'S POST-HOC MULTIPLE COMPARISONS TECHNIQUE: COMPARISONS BETWEEN JOB LEVELS IN RESPECT OF THE FIRST SCALE OF THE MCCQ

\begin{tabular}{|c|c|c|c|c|c|c|c|c|c|c|}
\hline \multirow[t]{2}{*}{ VARIABLES } & \multicolumn{4}{|c|}{ MEANS } & \multicolumn{6}{|c|}{ GROUPS } \\
\hline & $\begin{array}{l}\text { A } \\
\text { Consultant } \\
\mathrm{N}=56\end{array}$ & $\begin{array}{l}B \\
\text { Senior } \\
N=59\end{array}$ & $\begin{array}{l}\mathrm{C} \\
\text { Principal } \\
\mathrm{N}=31\end{array}$ & $\begin{array}{l}\text { D } \\
\text { Dir/Partner } \\
\mathrm{N}=19\end{array}$ & $A-B$ & $\mathrm{~A}-\mathrm{C}$ & A-D & $\mathrm{B}-\mathrm{C}$ & B-D & C-D \\
\hline X1 & 126,45 & 136,32 & 144,77 & 143,42 & $* *$ & $* *$ & $* *$ & * & & \\
\hline
\end{tabular}

* $\mathrm{p}=0,05 \quad * * \mathrm{p}=0,01$

TABLE 12

MANOVA AND ASSOCIATED ANOVA' FOR YEARS OF EXPERIENCE IN RESPECT OF THE THREE SCALES OF THE MCCQ

\begin{tabular}{cccc}
\hline Wilk's Coefficient Lambda & $\mathrm{F}$ & $\mathrm{df}$ & $\mathrm{p}$ \\
0,865939 & 3,98 & $6 \& 320$ & 0,0007 \\
& & & \\
X1 & 9,37 & $2 \& 162$ & $0,0001^{*}$ \\
X2 & 2,25 & $2 \& 162$ & 0,1083 \\
X3 & 1,73 & $2 \& 162$ & 0,1812 \\
\hline
\end{tabular}

* Statistically significant

\section{REFERENCES}

Alnutt, J.D. (1991). The corporate image of management consulting firms. Unpublished MBA research report submitted as partial fulfilment of the requirement of an MBA degree. Johannesburg: University of the Witwatersrand.

Bader, G. \& Stich, T. (1993). Building the consulting relationship. Training \& Development Journal, June, 55-60.

Barcus, S.W. \& Wilkinson, J.W. (1986). Handbook of management consulting services. New York: McGraw-Hill.

Bell, C.R. \& Nadler, L. (1979). The client-consultant handbook. Texas: Gulf

Blake, P. \& Mouton, B. (1987). Consultation. New York: Scientific Methods.

Block, P. (1981). Flawless consulting: A guide to getting your expertise used. Los Angeles: Pfeiffer.

Browne, M.W. (1979). The maximum-likelihood solution in inter-battery factor analysis. British Journal of Mathematical and Statistical Psychology, 32, 75-86.

Buchanan, D. \& Boddy, D. (1992). The expertise of the change agent. London: Prentice Hall.

Galagan, P.G. (1993). Training keeps the cutting edge sharp for the Andersen Companies. Training \& Development, January, 30-35.

Greiner, L.E. \& Metzger, R.O. (1983). Consulting to management. New Jersey: Cliffs Prentice-Hall.

Kable, J. (1991). Linking consultancy skills and consultancy preferences. Human Resource Management, August, 16-21.
TABLE 13

SCHEFFE'S POST-HOC MULTIPLE COMPARISONS TECHNIQUE: COMPARISONS BETWEEN YEARS OF EXPERIENCE IN RESPECT OF THE FIRST SCALE OF THE MCCQ

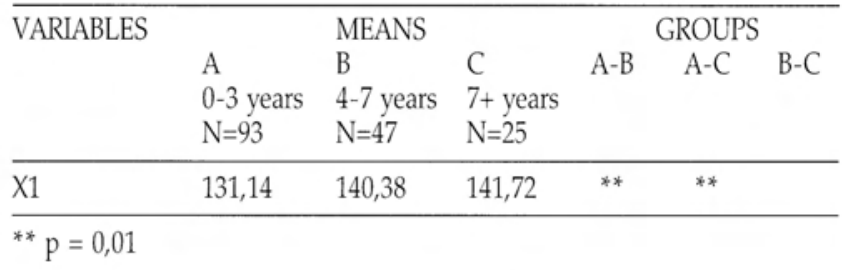

Kaiser, H.F. (1961). A note on Guttman's lower bound for the number of common factors. British Journal of Statistical Psychology, 14(1), 1.

Kubr, M. (Ed.). (1988). Management consulting: A guide to the profession (2nd ed.), International Labour Organisation.

Lippit, G. \& Lippit, R. (1986). The consulting process in action. San Francisco: University Associates.

Miller, P. (1992). Management consulting competence. Unpublished research report to the Faculty of Business Administration, Johannesburg, University of the Witwatersrand.

Moline, T. (1990). Upgrading the consultant. Journal of Management Consulting, 6(2), 17-22.

Parsons, J. (1993). Guessing games. Productivity SA. July/ August, 5-6.

Price, C.R. (1991). A new national program for consulting. Journal of Management Consulting, 6(4), 34-37.

Swanefelder, C. \& Schepers, J.M. (1992). Die faktore gemeenskaplik aan die selfondersoekvraelys van Holland en die Nuwe Suid-Afrikaanse Beroepsbelangstellings-vraelys. Tydskrif vir Bedryfsielkunde, 18(3), 6-12.

Tabachnick, B.G. \& Fidell, L.S. (1989). Using multivariate statistics. New York: Harper Collins.

Tucker, L.R. (1958). An inter-battery method of factor analysis. Psychometrika, 23, 111-136.

Tucker, L.R. \& Lewis, C. (1973). A reliability coefficient for maximum likelihood factor analysis. Psychometrika, 38, 1-10.

The South African Institute of Chartered Accountants, (1992). Management consulting. Johannesburg: Penrose. 